\title{
On Apteronotus magdalenensis (Miles, 1945) (Gymnotiformes: Apteronotidae): a poorly known species endemic to the río Magdalena basin, Colombia
}

\author{
Javier A. Maldonado-Ocampo ${ }^{1}$, Carlos David de Santana ${ }^{2}$ and William G. R. Crampton ${ }^{3}$
}

\begin{abstract}
Based on the examination of the two available paratypes and recently collected material, we present new data and information on the electric knifefish Apteronotus magdalenensis, a species endemic to the río Magdalena-Cauca basin in Colombia. Since Miles' description in 1945, this species was not collected until recent field work at the Torrents of Honda and additional localities. We present data on the external morphology, morphometrics, pigmentation and electric organ discharges (EODs), of A. magdalenensis. We also review its distribution, ecology and conservation status.
\end{abstract}

Basados en la revisión de los dos paratipos disponibles y material recientemente colectado, presentamos nuevos datos e informaciones del pez cuchillo eléctrico Apteronotus magdalenensis, una especie endémica de la cuenca del río MagdalenaCauca en Colombia. Desde su descripción en 1945 por Miles, esta especie no fue colectada hasta trabajo de campo llevado a cabo recientemente en los rápidos de Honda y localidades adicionales. Presentamos datos sobre la morfología externa, morformetría, pigmentación y descarga del órgano eléctrico (EOD) de A. magdalenensis. También revisamos su distribución, ecología y estatus de conservación.

Key words: Distribution, Endemism, Taxonomy, Trans-Andean, Ubidia.

\section{Introduction}

Apteronotus magdalenensis was described by Miles (1945) as a new genus and species, Ubidia magdalenensis, from the Torrents of Honda in the middle portion of the río Magdalena basin, Colombia. The description was based on three specimens collected by Luis Olaya in 1945. The holotype, now lost, was deposited in the Fishing and Hunting Section, of the Ministry of the National Economy, Bogotá, Colombia. The other two specimens, which are both still in good condition, were deposited as paratypes at the Natural History Museum, London (BMNH) and the United States National Museum, Washington D.C. (USNM).

Triques (1993) included A. magdalenensis in Apteronotidae (maintaining the generic name Ubidia) based on a single synapomorphy: the presence of a middorsal electroreceptive filament. Nevertheless, Triques was unable to determine the phylogenetic position of A. magdalenensis within the family, and suggested its position as incertae sedis. Mago-Leccia (1994), also considered the genus Ubidia as valid, and provided a list of diagnostic characters. Camposda-Paz (1995) discussed the relationships of Sternarchorhamphus Eigenmann, 1905 and A. magdalenensis based on the examination of the USNM paratype. He also recognized the genus Ubidia, and suggested that it is a member of the subfamily Sternarchorhynchinae. Albert \& Camposda-Paz (1998) performed a cladistic analysis of the order Gymnotiformes in which they assigned Ubidia to the genus Apteronotus sensu stricto. This classification was followed by Albert (2001) and Albert (2003). Triques (2005), in his analysis of intergeneric relationships in the Apteronotidae, revalidated Ubidia and, based on its color pattern placed it in the tribe Sternarchorhynchini (sensu Triques, 2005) as sistergroup to Platyurosternarchus. This placement was

${ }^{1}$ Universidade Federal do Rio de Janeiro, Setor de Ictiologia, Departamento de Vertebrados, Museu Nacional, Quinta da Boa Vista, 20940040 Rio de Janeiro, RJ, Brazil. gymnopez@gmail.com

${ }^{2}$ Museu Paraense Emílio Goeldi, Departamento de Ictiologia, Avenida Perimetral 1901, Terra Firme, $66077-830$ Belém, Pará, Brazil. apteronotidae@ig.com.br

${ }^{3}$ University of Central Florida, Department of Biology, 32816-2368, Orlando, FL,USA. crampton@mail.ucf.edu 
subsequently disputed by de Santana \& Vari (2010), who excluded A. magdalenensis from Sternarchorhynchini. de Santana \& Vari $(2009,2010)$ also described in detail the coloration patterns in both Platyurosternarchus and $A$. magdalenensis, and concluded that they are nonhomologous.

Herein we present new data and information of Apteronotus magdalenensis, including morphological characters, pigmentation and electric organ discharges (EOD), based on the examination of the two available paratypes, and material newly collected from the río Magdalena-Cauca basin. We also provide a revised diagnosis, which differentiates this species from other Apteronotus. Furthermore, we provide updated notes on the ecology, conservation status and distribution of this species.

\section{Material and Methods}

Measurements were taken as point-to-point linear distances using digital calipers with a precision of $0.1 \mathrm{~mm}$ as follows: total length (TL)-distance from the tip of the snout to the tip of the caudal fin; length to end of anal fin (LEA)-the distance from the tip of the snout to the end of the base of the anal fin; anal-fin base-the distance between the bases of the first and last rays of the anal fin; preanal-fin distance-the distance from the tip of the snout to the base of the first analfin ray; snout to anus-the distance from the tip of the snout to the anterior margin of the anus; snout to midsaggital dorsal organ-measured from snout to the anteriormost point of the midsaggital dorsal organ; maximum body depth-the vertical extent of the body at the beginning of the anal fin; head length (HL)-the distance from the tip of the snout to the posterodorsal angle of the opercular bone; head depth at eye-vertical distance measured at the eye; head depth at occiput-vertical distance at nape to ventral body border; head width-measured at the opercular region; snout length-the distance from the tip of the snout to the anterior margin of the eye; postorbital distance-the distance from the posterior margin of the eye to the posterodorsal limit of the opercular bone; eye diameter-the horizontal diameter of the eye; interorbital width-the width between the dorsal margins of the orbits; posterior naris to snout-the distance from the anterior border of the posterior naris to the tip of the snout; posterior naris to eye-the distance from the posterior border of the naris to the anterior margin of the eye; internarial distance-the distance between the posterior margin of the anterior naris and the anterior margin of the posterior naris; branchial opening-the height of the opening measured along the vertical; mouth length-the distance from the tip of the snout to the rictus of the mouth; pectoral-fin length-the distance from the base of the dorsalmost ray of the pectoral fin to the distalmost point on the margin of the fin; prepectoralfin distance-the distance from the tip of the snout to the base of the dorsalmost pectoral-fin ray. Anal and pectoral-fin ray counts were taken using a dissecting microscope with transmitted backlight. Vertebral counts were taken from radiographs. Abbreviations for institutions and collections are: BMNH, The Natural History Museum, London [formerly British Museum (Natural History)]; CIUA, Colección de Ictiologia, Universidad de Antioquia, Medellín, Colombia; CPUCO, Colección de peces, Universidad Católica de Oriente, Rionegro, Colombia; IAVHP, Instituto Alexander von Humboldt, Colección de Peces, Villa de Leyva, Colombia; UIS, Universidad Industrial de Santander, Bucaramanga, Colombia; USNM, National Museum of Natural History, Smithsonian Institution, Washington, DC.

Sex was assessed by dissection. The testes of mature males are white and smooth, whereas ovaries are packed with cream-colored eggs. We scored gonadal maturity using a modified version of Nikolsky's (1963) scale: In brief: stage $0=$ immature (no gonad development); stage 1 = immature (early development or resting); stage 2 = early maturing; stage $3=$ late maturing; stage 4 = pre-spawning; stage $5=$ spent.

Electric organ discharges (EODs) were recorded from specimens at the type locality using the procedure summarized in Crampton et al. (2008). In brief, fishes were recorded in a nylon-mesh envelope suspended in the center of a 1201 cooler containing water from the capture locality. Temperature was standardized to $27.0^{\circ} \mathrm{C}+/-0.2^{\circ} \mathrm{C}$ for at least five minutes before recording. Signals were amplified from tank-end nickelchromium electrodes using an AC-coupled amplifier (Signal Recovery SR-5113) and digitized with an analog-digital converter at $200 \mathrm{kHz}$ and 16 bits of resolution (National Instruments Daq-6052E). All EODs were saved as ASCII files for analysis in custom written MATLAB programs. EOD peak power frequency (PPF) was calculated by fast Fourier transform from $3 \mathrm{~s}$ blocks of signal. Fishes with damage to the caudal appendage, exceeding an estimated $5 \%$ of intact body length were excluded from analysis.

\section{Results}

\section{Apteronotus magdalenensis (Miles, 1945) Figs. 1-2}

Ubidia magdalenensis Miles, 1945: 461-463, figs. 10-12 [original description, illustration].-Triques, 1993: 119 [phylogenetic relationships].-Mago-Leccia, 1994: 37, fig. 56 [listing of genus; key to apteronotid genera; illustration; diagnosis].-Campos-da-Paz, 1995: 30, 33, 34 [phylogenetic relationships].-Campos-da-Paz, 2000: 526 [taxonomy]. -Mojica \& Castellanos, 2002: 187, 188 [endangered category; illustration].-Triques, 2005: 142 [phylogenetic relationships].

Apteronotus magdalenensis.-Albert \& Campos-da-Paz, 1998: 431 [new combination; phylogenetic relationships]. -Albert, 2001: 76 [phylogenetic relationships].-Albert, 2003: 499 [checklist].-Maldonado-Ocampo \& Albert, 2003: 153 [checklist].-de Santana et al., 2004: 2-9 [comparison to Apteronotus eschmeyeri].-de Santana \& MaldonadoOcampo, 2005: fig. 5b [illustration; key to species of Apteronotus in Colombia].-Maldonado-Ocampo et al., 


\section{a}

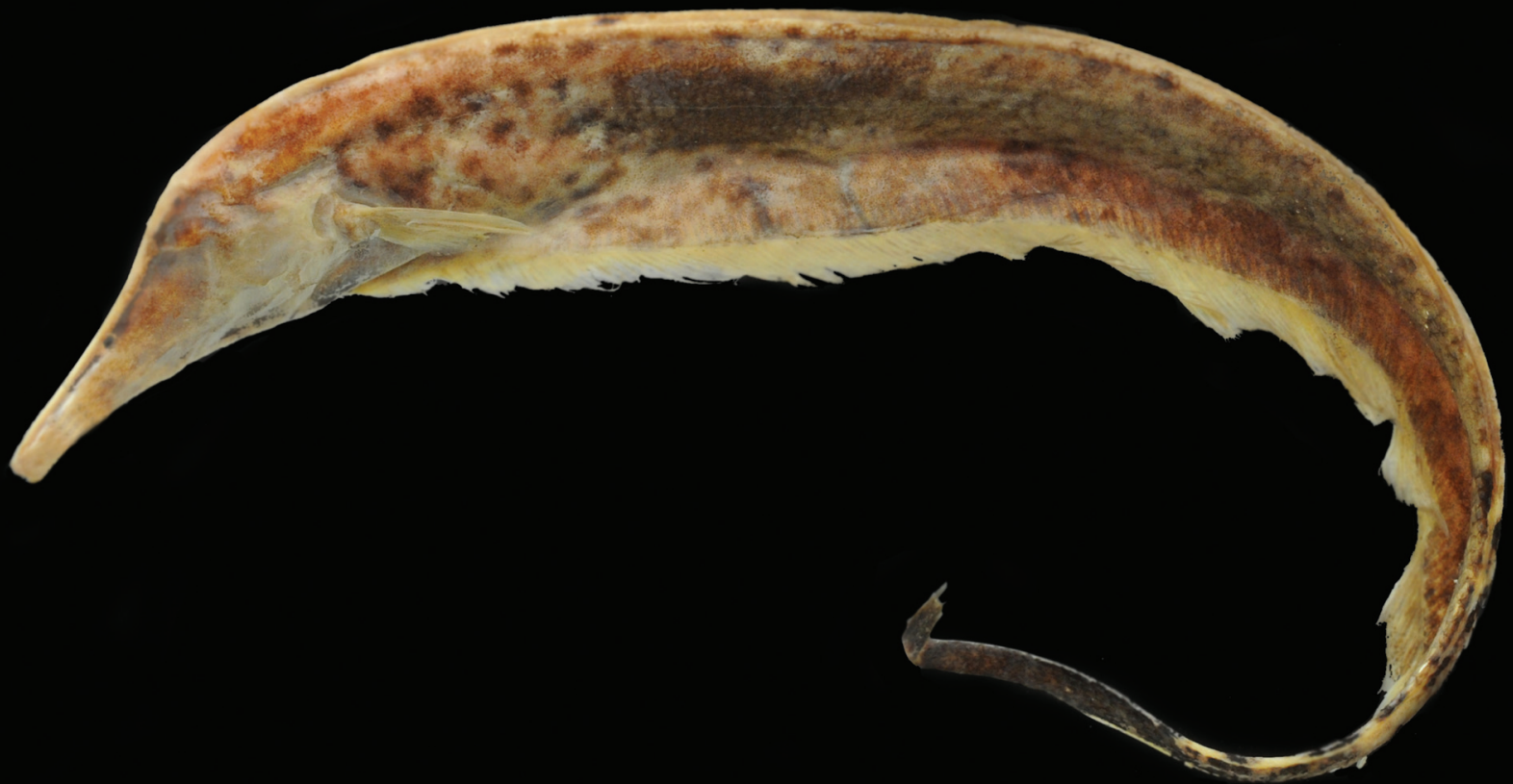

b

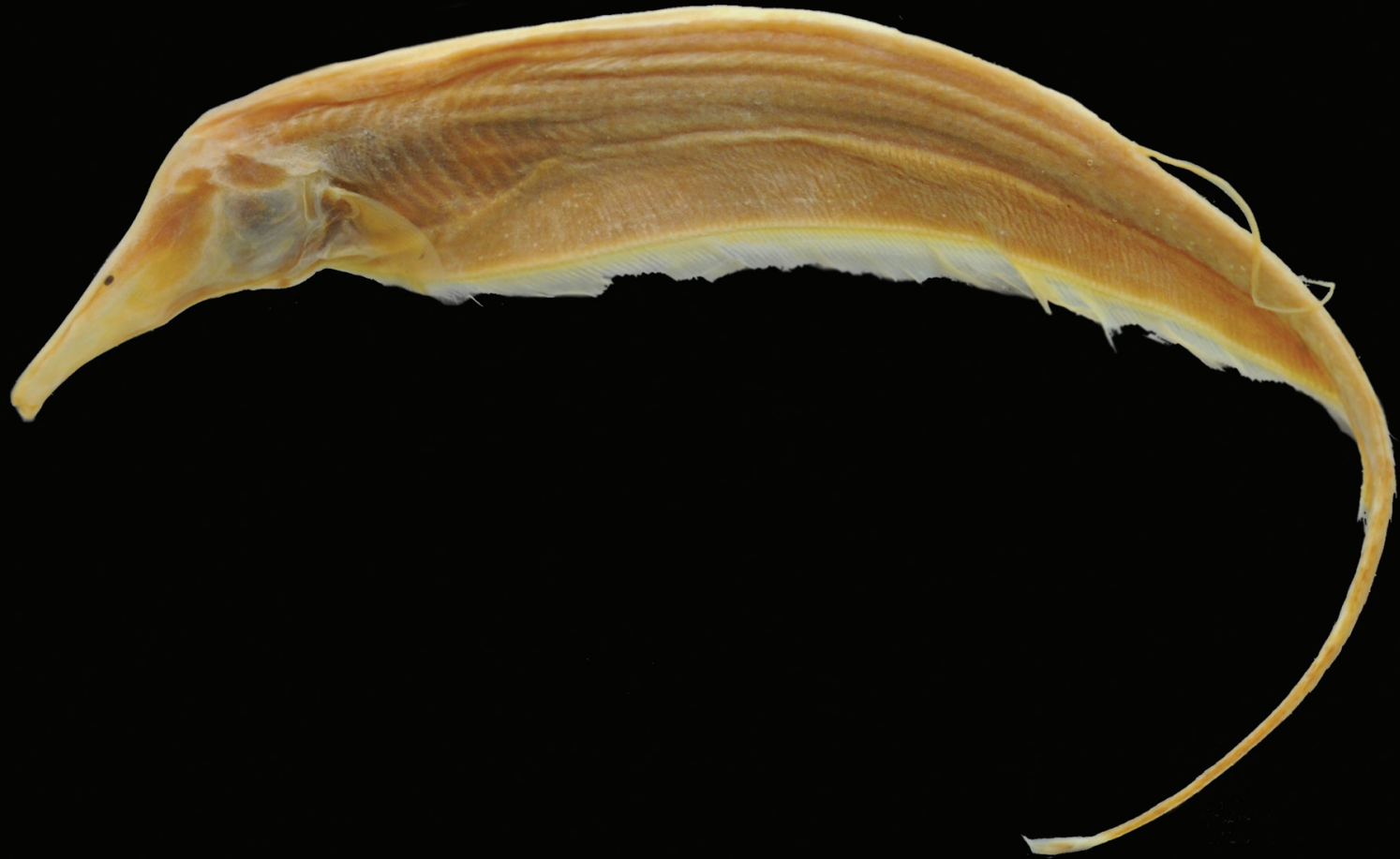

Fig. 1. Lateral view of the paratypes of Apteronotus magdalenensis: a) BMNH 1947.7.1.38, 335 mm TL.; b) USNM 123795, 287 mmTL. 
2005: 180, 294 [distribution; illustration].-Mojica et al., 2006: 34 [checklist]. -Villa-Navarro et al., 2006: 17 [checklist].Maldonado-Ocampo et al., 2008: 213 [checklist].-AgudeloZamora et al., 2009 [distribution extension].-Albert \& Crampton, 2009: 91 [snout elongation].

Diagnosis. Apteronotus magdalenensis belongs to Apteronotus sensu stricto and is distinguished from all other species by one autapomorphy: mouth rictus not reaching posterior naris.

Additional characters that helps to differentiate the species but not exclusive to A. magdalenensis among other species of Apteronotus sensu stricto are: sphenoid region of neurocranium more than one-third total head length in mature specimens (vs. sphenoid region of neurocranium less than one-third total head length in mature specimens, except $A$. cuchillo Schultz, 1949); body coloration blotchy (vs. even brown to black, except $A$. cuchillo and A. eschmeyeri de Santana, Maldonado-Ocampo, Severi \& Mendes, 2004); large body size, attaining a total length greater than $300 \mathrm{~mm}$ ( $v s$. attaining a total length smaller than $300 \mathrm{~mm}$, except $A$. cuchillo and A. eschmeyeri ); total number of anal-fin rays 180-213 [vs. 133-148 in A. camposdapazi de Santana \& Lehmann, 2006;
146-154 in A. caudimaculosus de Santana, 2003, 138-155 in A. cuchillejo (Schultz, 1949); 160-175 in A. eschmeyeri ; 145-165 in A. galvisi de Santana, Maldonado-Ocampo \& Crampton, 2007; 167 in A. jurubidae (Fowler, 1944); 145-156 in A. magoi de Santana, Castillo \& Taphorn, 2006; 130-165 in A. milesi de Santana \& Maldonado-Ocampo, 2005; 162-180 in A. mariae (Eigenmann \& Fisher, 1914); 153-162 in A. rostratus (Meek \& Hildebrand, 1913); 171-179 in A. spurrellii (Regan, 1914)]; the presence of scales on the middorsal region of body [ $\mathrm{vs}$. absence in A. ellisi (Alonso de Arámburu, 1957)]; and the presence of an ossified lateral ethmoid (vs. unossified in $A$. cuchillejo, A. rostratus, and A. spurrellii).

Description. Figs . 1-2 illustrate body shape and pigmentation. Table 1 presents morphometric and meristic data for Apteronotus magdalenensis. Maximum observed body size $449 \mathrm{~mm}$ TL (males) and $363 \mathrm{~mm}$ TL (females). No sexual dimorphism of cranial morphology (based on Principal Component Analysis of multiple morphometric landmarks in 13 males and 15 females). Body elongate. Dorsal profile straight. Maximum body depth at abdominal cavity or, slightly posterior. Lateral line extending to base of caudal fin, but absent on it. First perforated scale above pectoral-fin origin.

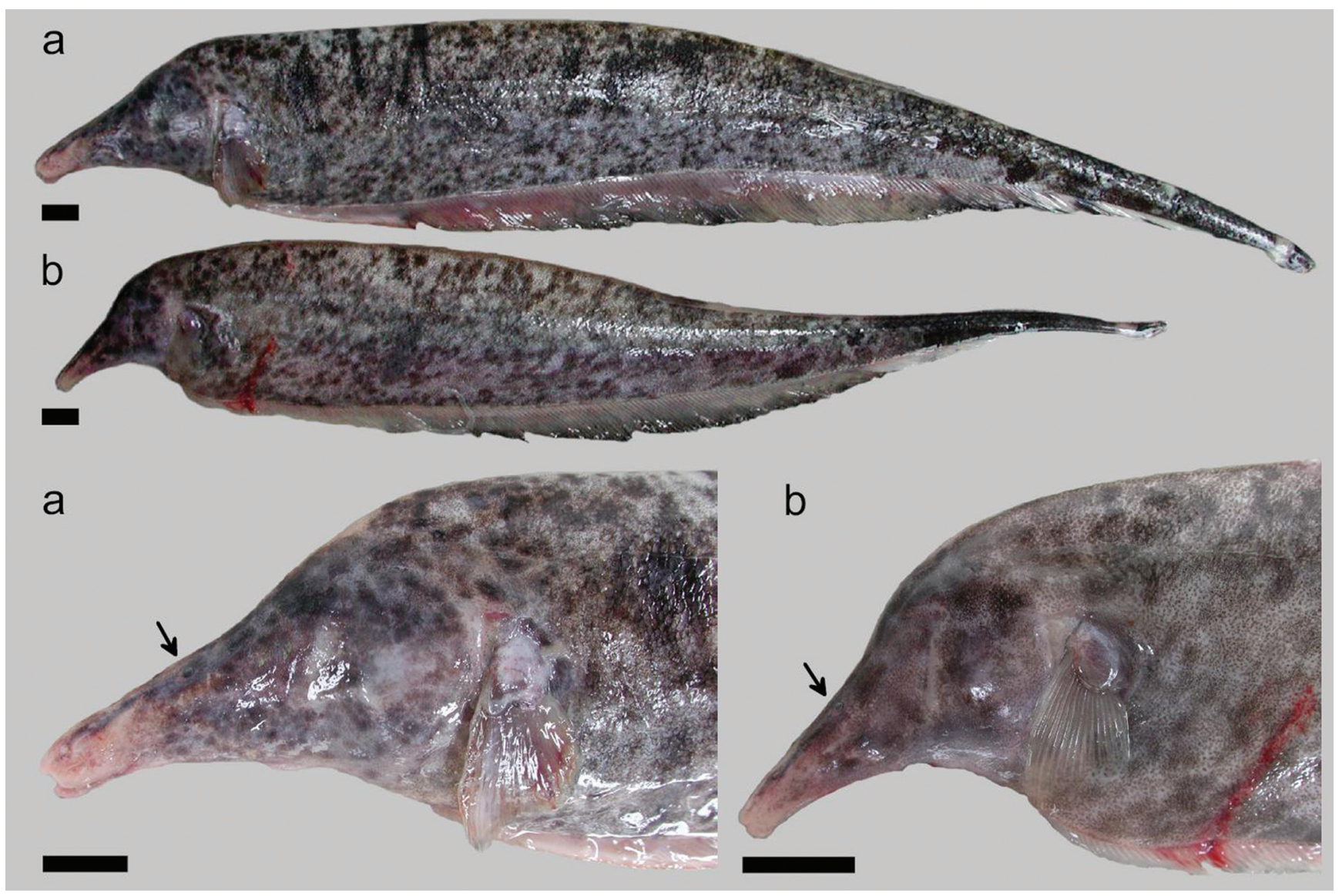

Fig. 2. Live specimens of Apteronotus magdalenensis, showing body and head. a) IAvH-P 9836 (WC 2005-09-27-01), male; b) IAvH-P 7026, (WC 2005-09-27-03), female. Scale bars = 10 mm. Arrows show position of eye. 
Table 1. Morphometric and meristic data for Apteronotus magdalenensis. Pooled $=32$ non-types combined.

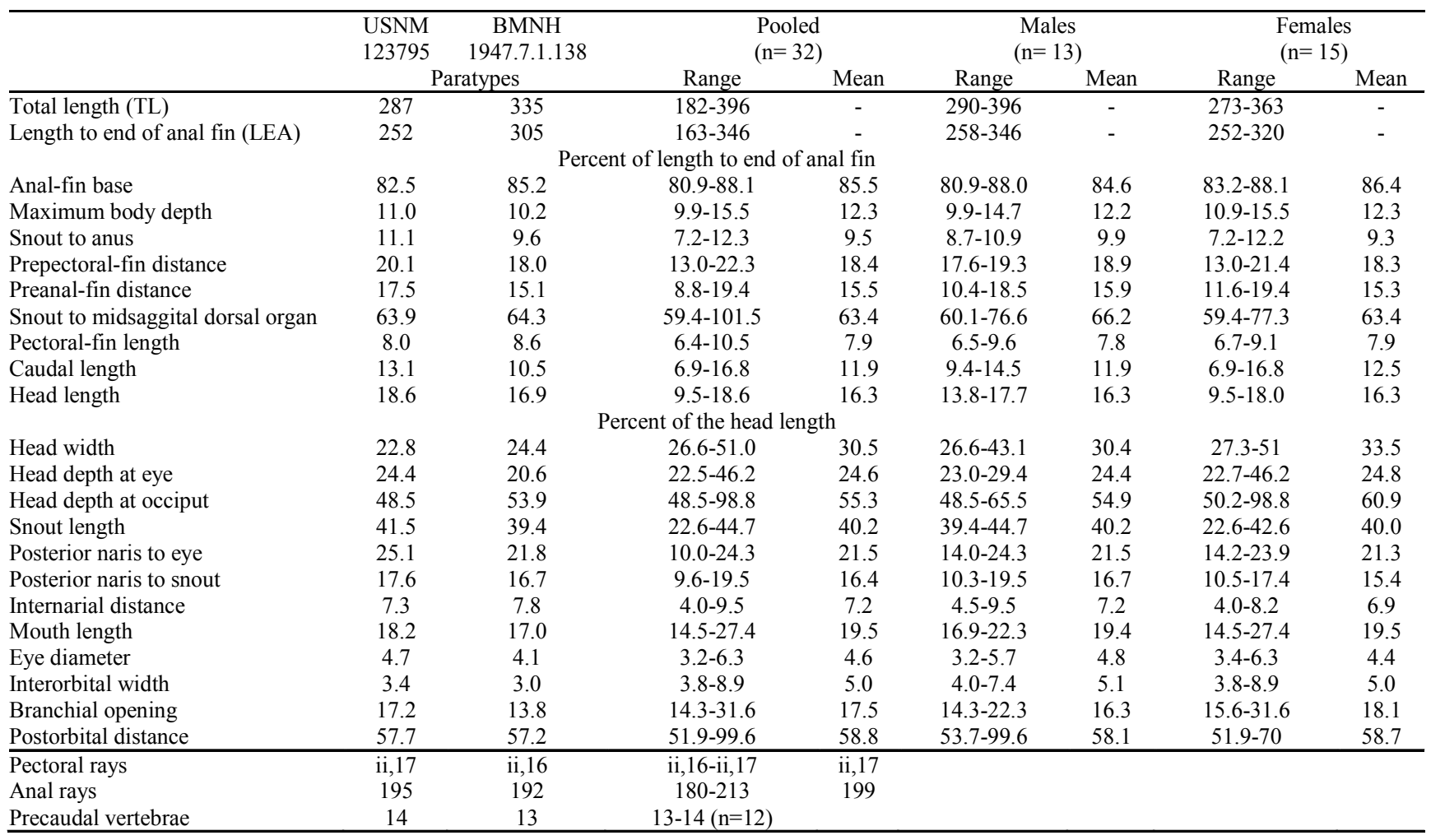

Head laterally elongate. Maximum head depth at occiput. Postorbital region distinct longer than preorbital portion of head. Eye very small 3.2-6.3 in HL ( $n=34)$, laterally located and covered by membrane. Mouth short 14.5-27.4 in HL ( $\mathrm{n}=32)$ and terminal. Mouth rictus not surpassing a vertical trough posterior naris. Upper jaw longer than lower jaw. Anus and urogenital papilla adjacent, ventral, at vertical posterior to eye. Dorsal mid-sagittal dorsal thong origin on posterior half of body and inserted into a narrow middorsal groove. Scales present on middorsal region of body. Pectoral fin somewhat elongated, broad and pointed distally, with ii,16-ii,19 rays $(n=34)$. Anal fin with 180-213 $(n=34)$ total anal-fin rays. $13-14$ precaudal vertebrae $(n=14)$.

Color in live specimens. (See Fig. 2). Base color light pinkish or light brown, with darker brown or black spots of small size and irregular shape forming a more or less dense marbled pattern with posterior increasing spot size. Towards caudal third, coloration becomes darker and pattern more dense to form a dark caudal end. Two thin creamy white bands, one in caudal peduncle and other in tip of caudal fin. Base of anal fin pinkish, with dark distal border in mid and posterior sections. Mottling intensified on head. Anterior portion of snout largely free of mottling.

Distribution. Apteronotus magdalenesis is endemic to the río Magdalena-Cauca basin in the trans-Andean region of
Colombia. Until May 2008, it was only known from the type locality in the Torrents of Honda, río Magdalena. However, recent collections performed at the lower stretches of the río Magdalena and río Cauca, captured four additional individuals, two in the main channel of the río Magdalena in the municipality of Puerto Berrio (186 km downriver from the type locality), one in the main channel of the río Sogamoso close to its confluence with the río Magdalena almost $210 \mathrm{~km}$ downriver from the type locality (Agudelo-Zamora et al., 2009), and one in the main channel of the lower río Cauca in the municipality of Caucasia (approximately $168 \mathrm{~km}$ from the confluence between the río Cauca and río Magdalena). These records extend the species distribution range in the río Magdalena-Cauca basin (Fig. 3).

Electric organ discharges (EOD). Apteronotus magdalenensis generates a continuous wave (tone) - type EOD with a stable fundamental frequency (cycle rate) of 534$996 \mathrm{~Hz}$ at $27.0^{\circ} \mathrm{C}+/-0.2^{\circ} \mathrm{C}$ (mean $709, \mathrm{SD} 129, \mathrm{n}=26$ ). The EOD waveform contains two phases of alternating polarity, corresponding to a type-C category of apteronotid EOD (following the classification of Crampton \&Albert, 2006), where there is a noticeable inflection in the ascending voltage component of the waveform, above the baseline (i.e. 0 volts). In Fig. 4 we present typical EODs from fully mature male and female specimens. We found no sexual differences in EOD discharge rate. Considering all mature specimens at Nikolsky 
stages 2-4, we noted no significant sex difference in the EOD fundamental frequency (males - $697 \mathrm{~Hz}, \mathrm{n}=9$, females - 671 $\mathrm{Hz}, \mathrm{n}=8$, df $15 p=0.61$ ). Considering all mature specimens at Nikolsky stages 3-4, we also noted no significant sex difference in the EOD fundamental frequency (males -691 $\mathrm{Hz}, \mathrm{n}=7$, females $-634 \mathrm{~Hz}, \mathrm{n}=8$, df $13, p=0.26$ ). Likewise, considering only fully mature specimens, at Nikolsky stage 4 , we still noted no significant difference in the EOD fundamental frequency (males $-691 \mathrm{~Hz}, \mathrm{n}=7$, females $-618 \mathrm{~Hz}, \mathrm{n}=4$, df 9, $p=0.24$ ). We also noted no obvious sex differences in EOD waveform shape. The Peak Power Frequency (PPF) of the power spectral density (Fig. 4) corresponds invariably to the fundamental frequency $(n=26)$. No spontaneous amplitude modulations (chirps) or other EOD modulations were observed. However, we suspect that in the absence of differences in EOD fundamental frequency and waveform shape between sexually mature males and females, must may be encoded by modulations of the EOD during courtship (see Turner et al., 2007).

Ecological notes. The type locality, the Torrents of Honda in the río Magdalena (Fig 5a), is located at approximately $250 \mathrm{~m}$ above sea level. The main channel of the river, which reaches about $10 \mathrm{~m}$ deep, is characterized by a rocky substrate

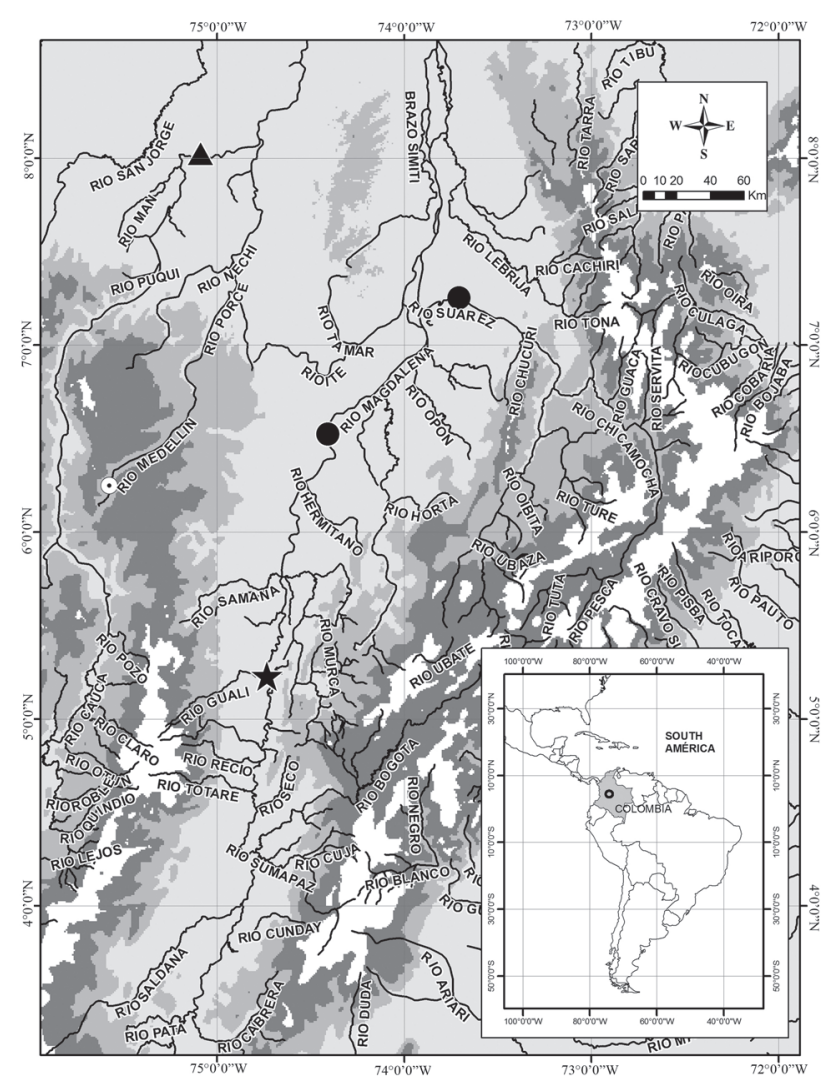

Fig. 3. Distribution of Apteronotus magdalenensis in the río Magdalena, Colombia. Star: type locality; Circles: additional records in the río Magdalena; Triangle: additional record in the lower río Cauca. comprising small stones to very large ( $>2 \mathrm{~m}$ diameter) boulders, with some gravel, sand, and mud beaches. There current is fast $\left(>1.5 \mathrm{~ms}^{-1}\right.$ in mid channel) and the water is turbid due to a high sediment load of suspended silt (Fig. 5a). In March 9122006 we recorded the following water quality parameters: dissolved oxygen, 5.0-5.2 $\mathrm{mg}^{-1}$; electrical conductivity, 140$150 \mu \mathrm{Scm}^{-1} ; \mathrm{pH}$ 6.2-6.4; transparency with Secchi disk 0.28-0.4 $\mathrm{m}$; temperature, $25.6-27.1^{\circ} \mathrm{C}$, with an average of $26.5^{\circ} \mathrm{C}$. We noted fluctuations in the water level of some 1-2 m over a period of less than $48 \mathrm{~h}$, corresponding to rain in upstream areas of the basin. The coolest temperatures corresponded to pulses of elevated water level. The locality records downstream of Honda, in the municipality of Puerto Berrio and Puerto Wilches (see Materials Examined) (AgudeloZamora et al., 2009), present similar conditions - white waters with heavy sediment load characteristics of the río Magdalena but with a slower current (Fig. 5b).

At the type locality, other Gymnotiformes that occur syntopically with A. magdalenensis are: Apteronotus eschmeyeri, A. mariae, Eigenmannia cf. virescens, Eigenmannia humboldtii (Steindachner, 1878) and Sternopygus aequilabiatus (Humboldt, 1805). We found males and females in reproductive condition in both the rainy and dry seasons - suggesting an extended breeding period. As has been reported for the majority of Gymnotiformes species, A. magdalenensis feeds on the larval stages of aquatic insects.

Remarks. The range of the total lengths (TL) of the type series is $280-335 \mathrm{~mm}$, however Miles (1945) reported that Apteronotus magdalenensis reach lengths approximating one meter (referring to A. magdalenensis, he wrote: "It has been found only at Honda, its extreme scarcity accounting for its absence from previous collections, although it attains a considerable size (about 1 meter), the type being somewhat smaller $280 \mathrm{~mm}$ "). We also noted that the total length of all collected individuals does not exceed $449 \mathrm{~mm}$ TL $(\mathrm{n}=33)$, with a minimum size of maturity of $301 \mathrm{~mm}$ TL in males ( $\mathrm{n}=$ $13)$, and $324 \mathrm{~mm}$ in females $(\mathrm{n}=15)$. Moreover, the maximum size for the species observed by local fishermen exceeds no more than $c a 500 \mathrm{~mm}$ TL. This leaves little doubt that Miles' (1945) comments refer instead to the syntopic species Sternopygus aequilabiatus, which apparently does reach lengths of a little more than one meter TL, according to local fishermen; we captured $S$. aequilabiatus at Honda to a maximum of $842 \mathrm{~mm} \mathrm{TL}$.

The anal and pectoral fins rays counts presented by Miles (1945) are respectively about 175 and ii,15, however the inspection of the two available paratypes shows higher values: 192-195 anal-fin rays and ii,16-ii,17 pectoral-fin rays. The differences in type series values between Miles description and the presented here, at least for anal-fin rays, could be result of the difficulty of counting the posterior fin rays at the end of the anal fin, without the aid of a dissecting microscope with transmitted backlight. Counting these rays from $\mathrm{x}$-rays images permitted the accurate counts we present here.

In the description by Miles (1945), the single illustration 

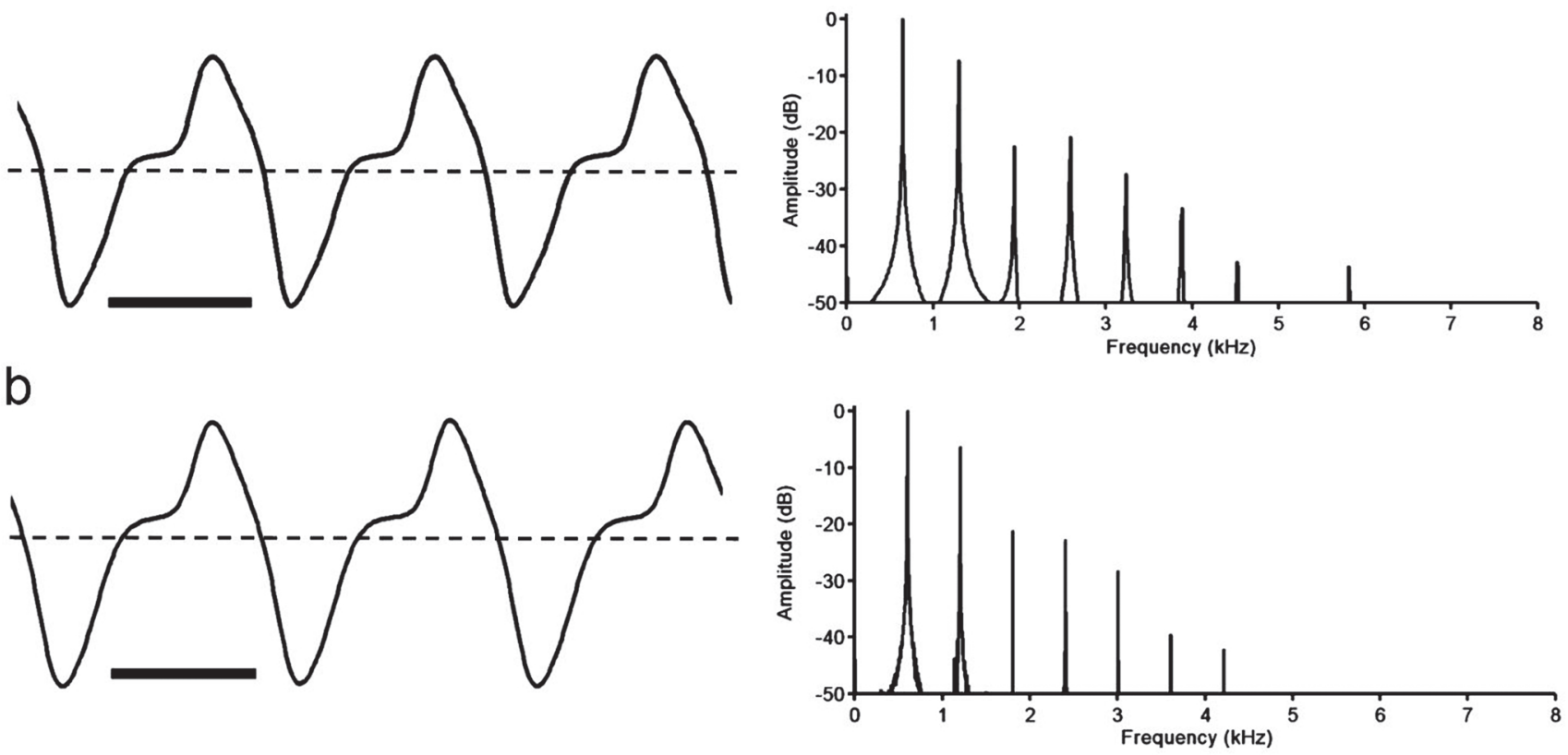

Fig. 4. Electric Organ Discharge (EOD) waveform (left) and Power Spectral Density (PSD) (right) of Apteronotus magdalenensis. (a): IAvH-P 9836, WC 2005-09-27-01, male, 360 mm TL, Nikolsky gonad stage 4 (fully mature). (b): IAvH-P 7026, WC 2005-0927-03, female, $326 \mathrm{~mm}$ TL, Nikolsky gonad stage 4 (fully mature). Waveforms are plotted head-positivity upwards, time on abscissa (scale $\mathrm{bar}=1 \mathrm{~ms}$ ), voltage on ordinate, horizontal dashed line $=0$ volts. PSD were computed by $65536=$ point fast Fourier transform from $3 \mathrm{~s}$ digital recordings. Amplitude on ordinate is scaled so that the peak power frequency is $0 \mathrm{~dB}$.

of A. magdalenensis indicate that the snout tip cross below a horizontal imaginary line through the origin of the anal-fin base. However, this condition is highly variable in the additional specimens collected at the type locality (for example the specimens in Fig. 2 do not exhibit this condition).

\section{Discussion}

Relationships. The position of Apteronotus magdalenensis within Apteronotus has been disputed. Albert \& Campos-daPaz (1998) and Albert (2001) placed A. magdalenensis as sister group to $A$. cuchillo in a so-called "clade J". In contrast Triques (2005) assigned $A$. magdalenensis to the Sternarchorhynchinae, a subfamily that included Sternarchorhynchus and Platyurosternarchus based on 10 putative synapomorphies. In Sternarchorhynchinae, $A$. magdalenensis was placed as a sister group to Platyurosternarchus macrostoma (Günther, 1870) based on the color pattern.

de Santana \& Vari (2010) discussed and refuted all 10 characters used by Triques (2005) to include $A$. magdalenensis in Sternarchorhynchinae. Moreover, the authors found that the color pattern and elongation of the snout in $A$. magdalenensis are superficially convergent with the condition in P. macrostoma. Another character mentioned by de Santana
$\&$ Vari (2010), the presence of lateral ethmoid in $A$. magdalenensis, was coded as unknown by Triques (2005), based on the illustration of cranial osteology in the original description. As mentioned by the de Santana \& Vari (2010), a lateral ethmoid is always present in the species of Apteronotus contrary to the derived absence of that element in Platyurosternarchus and Sternarchorhynchus. A phylogenetic analysis of Apteronotus is beyond the scope of the paper, but based on the evidence from body color pattern and the presence of lateral ethmoid we concur with Albert \& Campos-da-Paz (1998) and Albert (2001) in considering A. magdalenensis as a subunit of Apteronotus. Additional molecular evidence based on mitochondrial and nuclear DNA markers (unpublished data JAMO) indicate that A. magdalenensis and A. eschemeyeri are sister taxa, within Apteronotus sensu stricto.

Conservation. Apteronotus magdalenensis, was listed as a vulnerable species (Vulnerable - category C) in the Red Book of Freshwater Fishes of Colombia (Mojica et al., 2002). This categorization was based on the scarcity of information on the species, the paucity of capture records in the fifty-seven years since its description, and its restricted geographical range. Miles $(1945,1947)$ and Mojica \& Castellanos (2002), made reference to the low abundance of this species. 
Nonetheless, the data we compiled from the type locality, particularly the frequency with which local fisherman capture this species in their daily fishing activities, indicates that $A$. magdalenensis is common in the area. Apteronotus magdalenensis does not have any commercial value and is typically return alive as by-catch. Miles (1947) reported that people of the Torrents of Honda area consume this species. However, today the species appears to be only occasionally consumed, on a subsistence basis.

Although the current data indicate that the species no longer meets the criteria under which it was originally categorized as endangered (i.e. low abundance, shortage of records and restricted distribution), we argue that the category should be maintained because other factors like pollution and deforestation could be affecting local fish populations. High levels of pollution in the río Magdalena basin are known to be affecting local fish populations. For example, the deleterious effects of water pollution (untreated industrial and domestic wastewater, runoff of pesticides and fertilizers from agricultural lands, and wastes from mineral mining operations) have already been demonstrated in commercial species such as Prochilodus magdalenae Steindachner, 1879 and Pseudoplatystoma magdaleniatum Buitrago-Suárez \& Burr, 2007 (Cala, 2001). Pollution may also have influenced the distribution of other apteronotids, including Apteronotus mariae and A. eschmeyeri, which, at the beginning of the $20^{\text {th }}$ century, were both, collected in the ríos Apulo and Bogotá, but have since disappeared.

Material Examined: Colombia: BMNH 1947.7.1.138, paratype, (335 mm TL), Department of Tolima, Municipality of Honda, río Magdalena, Miles, Sep 1945; USNM 123795, paratype, (287 mm TL), Department of Tolima, Municipality of Honda, río Magdalena, Miles, Sep 1945; IAvHP 3138, 5 (two males, two females, and one juvenile 182-396 mm TL), Department of Tolima, 1-2 km south of the Municipality of Honda, principal channel of the middle reach of the río Magdalena, $05^{\circ} 13^{\prime} 45.7^{\prime} \mathrm{N} 74^{\circ} 43^{\prime} 59.5^{\prime \prime} \mathrm{W}$, MaldonadoOcampo, 1 Feb 2003; IAvHP 7026, 2 (females 295-326 mm TL, see Fig. 2 for larger specimen), same locality as IAvHP 3138, MaldonadoOcampo \& Crampton, 27 Sep 2005; IAvH-P 7829, 3 (one female, one male and one of indeterminate sex 225-317 mm TL), same locality as IAvHP 3138, Maldonado-Ocampo et al., 10 Mar,2006; IAvHP 7830, 2 (one female and one of indeterminate sex 290-359 mm TL), same locality as IAvH-P 3138, Maldonado-Ocampo et al., 11 Mar 2006; IAvHP 7831, 2 (males 301-357 mm TL), same locality as IAvHP 3138, Maldonado-Ocampo et al., 12 Mar 2006; IAvHP 7832,5 (two females, one male, and two of indeterminate sex 259$394 \mathrm{~mm}$ TL), same locality as IAvHP 3138, Maldonado-Ocampo et al., 13 Mar 2006; IAvHP 7833, 5 (three females, two males 284$383 \mathrm{~mm}$ TL), same locality as IAvHP 3138, Maldonado-Ocampo et al., 14 Mar 2006; IAvHP 7834, 6 (two females, three males and one of indeterminate sex 308-389 mm TL), same locality as IAvHP 3138, Maldonado-Ocampo et al., 15 Mar 2006; IAvHP 9523, 1 (male $323 \mathrm{~mm}$ TL), same locality as IAvHP 3138, MaldonadoOcampo \& Crampton, 27 Sep 2005; IAvHP 9524, 2 (females 305$355 \mathrm{~mm}$ TL), same locality as IAvHP 3138, Maldonado-Ocampo, 01 Feb 2003; IAvHP 9751, 2 (one female, one male 301-346 mm TL), same locality as IAvHP 3138, Maldonado-Ocampo \& Crampton, 27 Sep 2005; IAvHP 9836, 1 (male, 360 mm TL), same locality as IAvHP 3138, Maldonado-Ocampo \& Crampton, 27 Sep 2005; CIUA 959, 1 (female 375 mm TL), Department of Antioquia, Municipality of Puerto Berrio, mouth of La Malena stream, río Magdalena 0631'28.23'N 74²4'25.72'W, Agudelo-Zamora et al., 20 Jul 2008; CIUA 1168, 1 (270 mm SL, damaged caudal portion), Department of Antioquia, Municipality of Puerto Berrio, mouth of La Malena stream, río Magdalena 06³1'25.46”N , 74²4'36.92”W, Alvarez et al., Oct 2009; CP-UCO 1764, 1 (male 449 mm TL), Department of Antioquia, Municipality of Caucasia, Ciénaga de la Ilusión, Cauca River, 0801'26.9'N 7505'19.6”W, Zuluaga-Gómez, Oct 2010; UIS uncataloged specimen, 1 (405 mm TL), Department of Santander, Municipality of Puerto Wilches, Sogamoso River at Puerto Cayumba, 7013'35.41'N 73º 39'19.70’W, Pelayo-Villamil \& Mantilla, 27 Oct 2009.
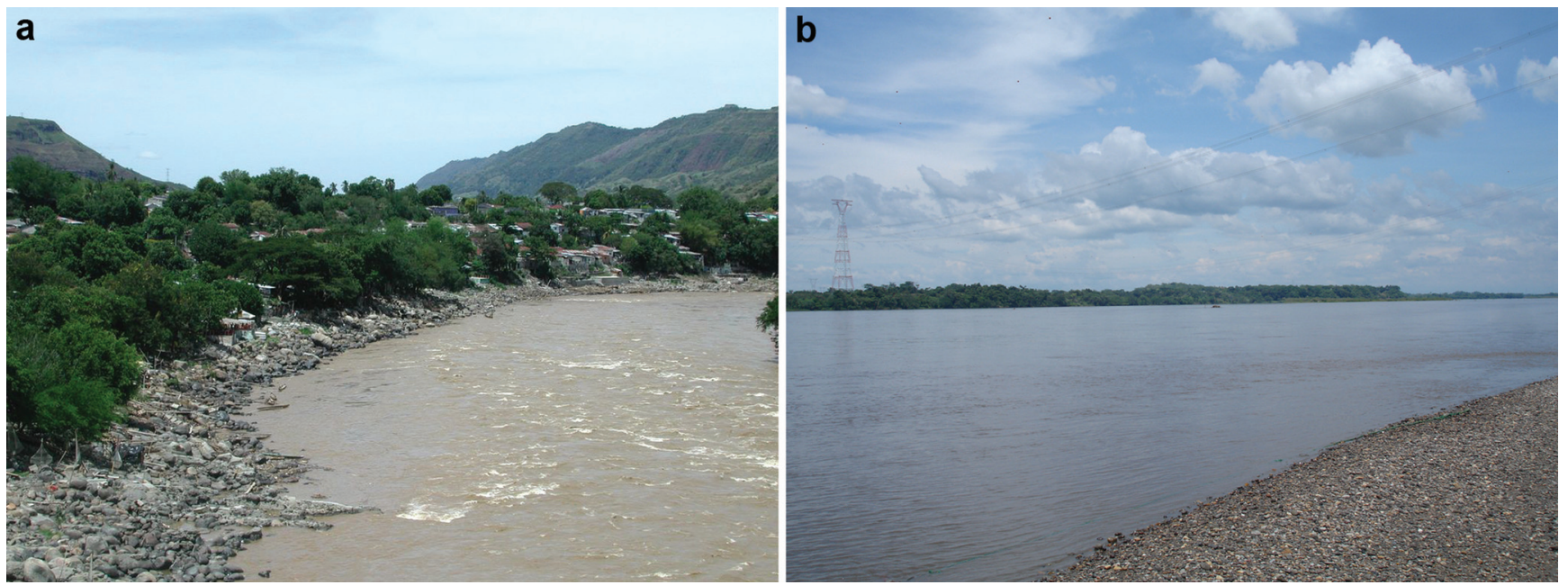

Fig. 5. General view of the habitat of Apteronotus magdalenensis in the río Magdalena. a: type locality Torrents of Honda; b: mouth of La Malena stream near Puerto Berrio in Antioquia Department (Photo a: Willian Crampton; photo b: courtesy of Pelayo-Villamil and Ochoa-Orrego). 


\section{Acknowledgments}

The Alexander von Humboldt Institute funded research associated with the project through the Endangered Species Program. We thank Lucho family, Germán Gálvis, Lina Mesa and Jorge Sinisterra for their support in field work. Henry Agudelo and Alejandro Zuluaga provide the new data about the distribution of the species. For museum and technical support and/or loan of material we thank Richard Vari, Sandra Raredon (NMNH), James Maclaine (BMNH), Hernán López Fernández (ROM) and Nathan R. Lovejoy (University of Toronto). JAMO was funded by a Short Term Visitor Travel Grant at the National Museum of Natural History and is grateful to TWAS-CNPq Postgraduate Fellowships program for support during this project. WGRC received support from National Science Foundation grant DEB-0614334. CDS was supported by a Postdoctoral fellowship at the Crampton lab, and to a fellowship from the Conselho Nacional de Desenvolvimento Científico e Tecnológico (CNPq) and Fundação de Amparo à Pesquisa do Estado do Pará (FAPESPA).

\section{Literature Cited}

Agudelo-Zamora, H., P. Pelayo-Villamil, L. E. Ochoa-Orrego \& L. F. Jiménez-Segura. 2009. Fish, Gymnotiformes, Apteronotidae, Apteronotus magdalenensis (Miles, 1945): distribution extension of the endangered endemic Knifefish, in northern Colombia, Checklist, 5: 879-881.

Albert, J. S. 2001. Species diversity and phylogenetical systematics of American knifefishes (Gymnotiformes, Teleostei), Miscellaneous Publications, Museum of Zoology, University of Michigan, 190: 1-129.

Albert, J. S. 2003. Family Apteronotidae. Pp. 503-508. In: Reis, R. E., S. O. Kullander \& C. J. Ferraris (Eds.). Checklist of the Freshwater Fishes of South and Central America. Porto Alegre, Edipucrs, 729p.

Albert, J. S. \& R. Campos-da-Paz. 1998. Phylogenetic systematics of Gymnotiformes with diagnoses of 58 clades: a review of available data. Pp. 419-446. In: Malabarba, L. R., R. E. Reis, R. P. Vari, Z. M. S. Lucena \& C. A. S. Lucena (Eds.). Phylogeny and Classification of Neotropical Fishes. Porto Alegre, Edipucrs, $603 p$.

Albert, J. S. \& W. G. R. Crampton. 2009. A new species of electric knifefish, genus Compsaraia (Gymnotiformes: Apteronotidae) from the Amazon River, with extreme sexual dimorphism in snout and jaw length. Systematics and Biodiversity, 7: 81-92.

Cala, P. 2001. Occurrence of Mercury in some commercial fish species from the Magdalena and Meta Rivers in Colômbia. Dalhia, 4: 15-19.

Campos-da-Paz, R. 1995. Revision of South American freshwater fishes genus Sternarchorhamphus Eigenmann, 1905 (Ostariophysi: Gymnotiformes: Apteronotidae), with notes on its relationships. Proceedings of the Biological Society of Washington, 108: 29-44.

Campos-da-Paz, R. 1999. New species of Megadontognathus from the Amazon Basin, with phylogenetic and taxonomic discussions on the Genus (Gymnotiformes: Apteronotidae). Copeia, 1999: 1041-1049.
Campos-da-Paz, R. 2000. On Sternarchorhynchus Castelnau: A South American Electric Knifefish, with Descriptions of Two New Species (Ostariophysi: Gymnotiformes: Apteronotidae). Copeia, 2000: 521-535.

Campos-da-Paz, R. \& J. S. Albert. 1998. The gymnotiform “eels" of tropical America: a history of classification and phylogeny of South American electric knifefishes (Teleostei: Ostariophysi: Siluriphysi). Pp. 401-418. In: Malabarba, L. R., R. E. Reis, R. P. Vari, Z. M. S. Lucena \& C. A. S. Lucena (Eds.). Phylogeny and Classification of Neotropical Fishes. Porto Alegre, Edipucrs, 603p.

Crampton, W. G. R. \& J. S. Albert. 2006. Evolution of electric signal diversity in gymnotiform fishes. Pp. 647-696 and 718731. In: Ladich, F., S. P. Collin, P. Moller \& B. G. Kapoor (Eds.). Communication in Fishes. Enfield, NH., Science Publishers, 870p.

Crampton, W. G. R., J. K. Davis, N. R. Lovejoy \& M. Pensky. 2008. Multivariate classification of animal communication signals: a simulation-based comparison of alternative signal processing procedures using electric fishes. Journal of Physiology, 102: 304-321.

Mago-Leccia, F. 1994. Electric fishes of continental water of continental waters of America. Fundacion para el Desarrollo de las Ciencias Fisicas, Matematicas y Naturales, Caracas, Venezuela, $216 \mathrm{p}$.

Maldonado-Ocampo, J. A. \& J. S. Albert. 2003. Species diversity of gymnotiforms fishes (Gymnotiformes, Teleostei) in Colombia. Biota Colombiana, 4: 145-163.

Maldonado-Ocampo J. A., A. Ortega-Lara, J. S. Usma Oviedo, G. Galvis, F. Villa-Navarro, L. Vásquez, S. Prada-Pedreros \& C. A. Rodríguez. 2005. Peces de los Andes de Colombia. Guía de campo. Instituto de Investigación de Recursos Biológicos “Alexander von Humboldt," Bogotá, Colombia, 346p.

Maldonado-Ocampo, J. A., R. P. Vari \& J. S. Usma. 2008. Checklist of the freshwater fishes of Colombia. Biota Colombiana, 9: 143-237.

Miles, C. 1945. Some new recorded fishes from Magdalena River System. Caldasia, 15: 453-463.

Miles, C. 1947. Los Peces del río Magdalena. Ministerio de la Economía Nacional, Sección de Piscicultura, Pesca y Caza. Editorial el Gráfcio, Bogotá, Colombia, 214p.

Mojica J. I. 1999. Lista preliminar de las especies de peces dulceacuícolas de Colombia. Revista de la Academia Colombiana de Ciencias Exactas, Físicas y Naturales, 23(Suplemento Especial): 547-565.

Mojica, J. I. \& C. Castellanos. 2002. Ubidia magdalenensis. Pp. 187-188. In: Mojica, J. I., C. Castellanos, S. Usma \& R. Álvarez (Eds.). 2002. Libro rojo de peces dulceacuícolas Colombianos. La serie Libros Rojos de Especies Amenazadas de Colombia. Instituto de Ciencias Naturales Universidad Nacional de Colombia, Ministerio del Medio Ambiente. Bogotá, Colombia, 285p.

Mojica J. I., G. Galvis, F. Arbeláez, P. Sánchez-Duarte, C. Castellanos \& F. A. Villa-Navarro. 2006. Peces del valle medio del río Magdalena, Colombia. Biota Colombiana, 7: 23-38.

Nikolsky, G. V. 1963. The Ecology of Fishes. Academic Press, New York, USA, 352p.

de Santana, C. D. \& J. A. Maldonado-Ocampo. 2005. A new species of ghost knifefish (Gymnotiformes: Apteronotidae) from the Cauca River, with a key to apteronotids from the MagdalenaCauca basin, Colombia. Ichthyological Exploration of Freshwaters, 16: 223-230.

de Santana, C. D., J. A. Maldonado-Ocampo \& W. G. R. Crampton. 2007. Apteronotus galvisi, a new species of electric ghost 
knifefish from the río Meta basin, Colombia (Gymnotiformes: Apteronotidae). Ichthyological Explorations of Freshwater, 18: 117-124.

de Santana, C. D., J. A. Maldonado-Ocampo, W. Severi \& G. N. Mendes. 2004. Apteronotus eschmeyeri, a new species of ghost knifefish from the Magdalena Basin, Colombia (Gymnotiformes: Apteronotidae). Zootaxa, 410: 1-11.

de Santana, C. D. \& R. P. Vari. 2009. The South American electric fish genus Platyurosternarchus (Gymnotiformes: Apteronotidae). Copeia, 2009: 233-244.

de Santana, C. D. \& R. P. Vari. 2010. Electric fishes of the genus Sternarchorhynchus (Teleostei, Ostariohysi, Gymnotiformes); phylogenetic and revisionary studies. Zoological Journal of the Linnean Society, 159: 223-371.

Triques, M. L. 1993. Filogenia dos gêneros de Gymnotiformes (Actinopterygii, Ostariophysi), com base em caracteres esqueléticos. Comunicações do Museu de Ciências de PUCRS, série Zoologia, 6: 85-130.

Triques, M. L. 2005. Análise cladística dos caracteres de anatomia externa e esquelética de Apteronotidae (Teleosei: Gymnotiformes). Lundiana, 6: 121-149.

Turner, C. R., M. Derylo, C. D. de Santana., J. A. Alves-Gomes \& G. T. Smith. 2007. Phylogenetic comparative analysis of electric communication signals in ghost knifefishes (Gymnotiformes: Apteronotidae). Journal of Experimental Biology, 210: 41044122.

Villa-Navarro, F. A., P. T. Zúñiga-Upegui, D. Castro-Roa, J. E. García-Melo, L. J. García-Melo \& M. E. Herreda-Yara. 2006. Peces del alto Magdalena, cuenca del río Magdalena, Colombia. Biota Colombiana, 7: 3-22.

Submitted February 9, 2010

Accepted June 27, 2011

Published September 16, 2011 